\title{
Law on environmental protection to be revised for sustainable development in Vietnam
}

\author{
Nguyen Khanh $\mathrm{Bui}^{{ }^{*}}$, and Anna Kopytova ${ }^{2}$ \\ ${ }^{1}$ Graduate Academy of Social Science, 477 Nguyen Trai Street, Hanoi, 10000, Vietnam \\ ${ }^{2}$ Tyumen Industrial University, Volodarskogo str., 38, Tyumen, 625000, Russia
}

\begin{abstract}
Law on Environmental Protection 2014 of Vietnam was passed by the 13 National Assembly at the 7th session on June 23, 2014, effectived from January 1, 2015. The enactment of the Law on Environmental Protection 2014 has greatly contributed to the success of environmental protection in recent years. However,the implementation of the Law on Environmental Protection 2014 revealed limitations and shortcomings, including: Some provisions of the law on environmental protection are still inappropriate, not reality, lack of legal provisons for Environmental disasters, not keeping up with the requirements of practical development and international integration; mechanisms and policies on environmental protection are slow to innovate, not yet synchronized with the market economy institution; contents, responsibilities, assignment and decentralization of state management of environmental protection are still fragmented, overlapping and unreasonable, not suitable with capacity building and responsibilities; lack of appropriate mechanisms to promote the effective participation of society, enterprises and people in environmental protection. Based on Law on Environmental Protection 2014, the state management apparatus on environment is not commensurate with the assigned functions and tasks and unable to solve effectively inter-sectoral, inter-regional and transnational issues; violations of the law on environmental protection are still complicated and invalid; The administrative procedures are both insufficient, overlapping; Vietnam has not legal provisions to resolve some new issues arising on environmental protection such as: climate changes, metal pollution heavy $(\mathrm{Cu}, \mathrm{Zn}, \mathrm{Cd})$, saline intrusion, dust pollution...This article focuses on the challenges of environment in Vietnam. It also provides causes and suggestion for Law on Environmental Protection 2014 to be revised for sustainable development in Vietnam.
\end{abstract}

\section{Introduction}

The most important lesson in Vietnam's sustainable development process is the Government's strong commitment and determination in the implementation of sustainable development objectives. From the central to local levels, Vietnam has been strongly committed to sustainable development with a systematic and aggregate approach; it has

*Corresponding author: khanhlaw75@yahoo.com 
nationalized international sustainable development objectives and integrated them in national development strategies, plans and programs. The Vietnamese Government has, at an early date, promulgated a National Plan on Environment and Sustainable Development for 1991-2000 and, since 1991, actively implemented it. The sustainable development approach has been asserted in successive Party Congresses' documents and the Socio Economic Development Strategy for 2001-2010, namely "Rapid, efficient and sustainable development, with economic development linked to exercise of social progress and equity and environmental protection". It has been reconfirmed in the Socio Economic Development Strategy for 2011-2020, namely "Rapid development linked to sustainable development, with sustainable development as a constant requirement in the whole Strategy".

Following the World Summit on Sustainable Development in Johannesburg, South Africa, the Government has promulgated Vietnam Agenda 21 (The "Strategic Orientation for Sustainable Development in Vietnam" was issued by Decision No. 153/2004/QD-TTg of Prime Minister on 17 August 2004) and, recently, the Vietnam Sustainable Development Strategy for 2011-2020. Thorough implementation of sustainable development objectives is the responsibility of the entire government system from the central to local levels in Vietnam's socio-economic development. The Vietnamese Government has also made major efforts in deploying national target programs and action plans for the attainment of sustainable development and millennium objectives. The Government's sustainable development efforts have also been manifested in its signing and implementation of international sustainable development conventions and commitments. For the realization of sustainable development objectives, many directives, resolutions and normative legal documents have been promulgated and implemented, especially Law on Environmental Protection 2014.

Based on practical results after nearly 5 years of implementing the Law on Environmental Protection 2014 shows that besides some positive results (Vietnam Law and Legal Forum (2016), the Law has revealed the shortcomings and limitations, which need to be amended and supplemented to resolve the current environmental challenges in Vietnam.

This review was developed by discussing challenges of environment in Vietnam, focus mainly in shortcomings and limitations of Law on Environmental Protection 2014 with the data and supported by Ministry of Natural Resources and Environment (MONRE) and Environment and Natural Resources Department of Provinces in Vietnam.

\section{Materials and Methods}

This paper discusses literature review as a methodology and is based on published data of Vietnam Environment Administration, Ministry of Natural Resources and Environment (MONRE) and Environment and Natural Resources Department of Provinces in Vietnam from 2014-2018. This paper uses the comparison and analysis methods to analyzes and compares the provisions of Law on Environmental Protection 2014 and pratical implementation of such regulations.

It shall be noted that environmental data collected mainly official information, omitting an undefined number of pending cases for further investigation. Neither skills, equipment nor integrity variables were available and taken into account for this article.

\section{The challenges of environment in Vietnam}

Environmental pollution, climate change, biodiversity decline, deforestation and degradation of land, water resources and declining ocean health reduction ... continues to be 
major, global issues, changing natural ecology systems, worldwide socio-economic life, become one of the greatest challenges facing humanity. The world has really entered industrial revolution 4.0 with the trend of interdependence among nations is more closely, especially for developing countries like Vietnam (Hansjorg Herr/Erwin Schweisshelm/Truong Minh Vu (2016). If it has not the active preventions and control measures, Vietnam will become a black technological waste of the world.

Implementing the line of "proactive and active international integration," in the past years, Vietnam's international integration process has reached a new height in all fields, which leads to Vietnam being more vulnerable to environmental problems regional and global, especially environmental issues of the lines of national trade and cross-border pollution (Vu Van Hien, 2019). Regional and world environments are facing issues emerging, typically climate change and rising sea issues; polluted air environment, transboundary water environment; increase plastic waste, import scrap and biodiversity decline.

Climate change continues to move fast, complicated and strong impacts environment, seriously threatening water security, ecological security and security food security, is the present risk to the implementation of the target sustainable development of Vietnam. The impact of climate change makes pollution, environmental degradation, biodiversity decline in Vietnam more complicated, more unpredictable.

Based on published data of Vietnam Environment Administration, Ministry of Natural Resources and Environment (MONRE) and Environment and Natural Resources Department of Provinces in Vietnam from 2014-2018, Vietnam's environment is facing great challenges in the coming years.

\subsection{Environmental pollution will be increased and complicated}

Water pollution in the river basins has not been improved, the problem of inundation in cities tends to expand and increase. In most river basins, there are environmental pollution spots with different pollution levels. Many parts of the river have been prolonged pollution such as the pollution of Nhue river, To Lich river in Hanoi City, Ngu Huyen Khe river in Bac Ninh; a system of flowing canals. through Districts 8, Binh Chanh, Hoc Mon (Ho Chi Minh City) .... Besides, a new hot spot on water environment pollution (the Chau Giang river section, the Bac Hung Hai river system, ...). The main reason is due to untreated or unsatisfactory discharge of wastewater sources from industrial zones production facilities, domestic wastewater, services in urban areas and wastewater from Mining activities at the headwaters have polluted surface water sources.

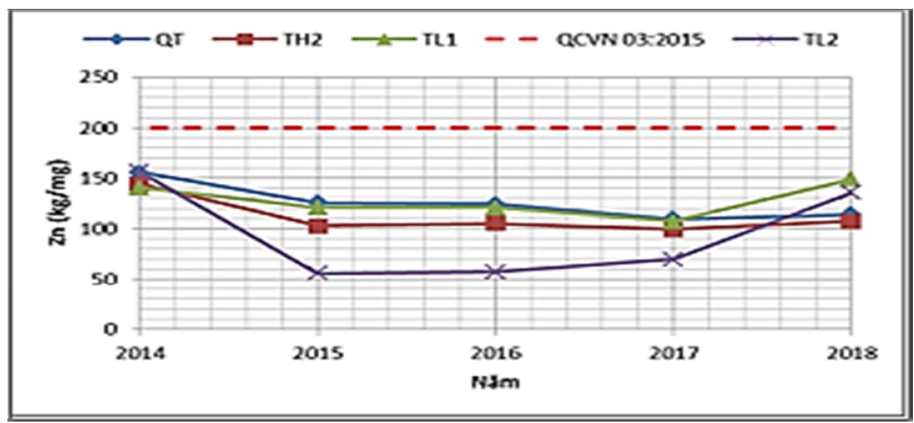

Fig. 1. WQI value ratio at the monitoring points in river basins in Vietnam during 2014-2018 (Source: Vietnam Environment Administration, Ministry of Natural Resources and Environment, 2019) (MONRE 2020) 
Dust pollution in urban areas is complicated. Air pollution in big cities is complicated and tends to increase at some time of the day and some days of the year, especially when there is a combination of meteorological and climatic factors. Weather phenomena of fog is increasing sources of air pollution. Air quality index (AQI) sometimes exceeded safety threshold, which is harmful to people's health (such as fine dust PM2.5, SO2, CO, ...). The renovation and new construction of national highways, the system of inner and inner roads also spread into the environment a huge amount of dust, causing air pollution to the surrounding areas.

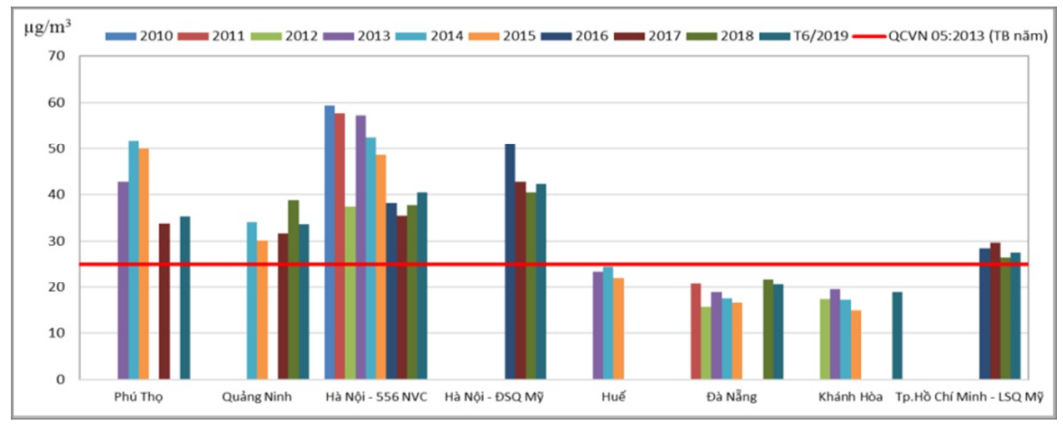

Fig. 2. The average value ratio of PM2.5 dust at the automatic monitoring points in Vietnam during 2010-2019 (Source: Vietnam Environment Administration, Ministry of Natural Resources and Environment, 2019) (MONRE 2020)

Environmental pollution in industrial/export processing zones and craft villages is increasing. Vietnam currently has 274 operating industrial/export processing zones, in which 244 industrial/export processing zones have complete centralized wastewater treatment systems and come into operation, with a capacity of over 950 thousand $\mathrm{m} 3 /$ day, the proportion of industrial/export processing zones with centralized wastewater treatment systems in 2019 will reach $89 \%$. Untreated wastewater from these industrial/export processing zones continues to pollute receiving sources.

Environmental pollution in many craft villages has become more and more serious. Some types of craft villages, especially recycled waste craft villages, are also causing serious environmental pollution, directly affecting the health of a large part of people in these areas and surrounding areas.



Fig. 3. BOD5 value ratio at the monitoring points on Cau River, in the Cau river basins in Vietnam during 2013-2019 (Source: Vietnam Environment Administration, Ministry of Natural Resources and Environment, 2019) 


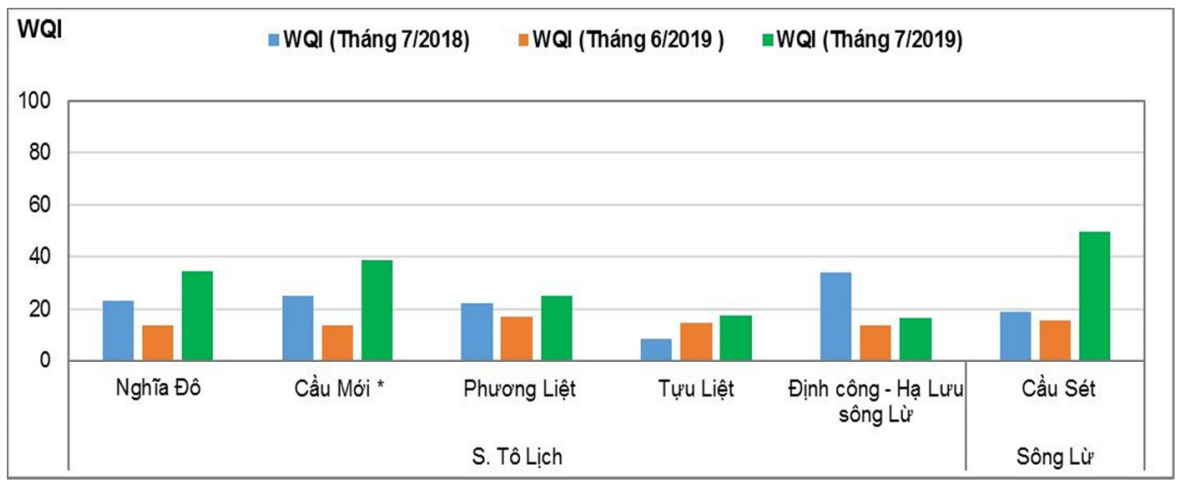

Fig. 4. WQI value ratio at the monitoring points in rivers in Hanoi during 2018-2019 (Source: Vietnam Environment Administration, Ministry of Natural Resources and Environment, 2019) (MONRE 2020)

Pollution at sea is complicated and no effective response measures. Pollution in the East Sea is complicated and has no effective response measures. The situation of marine waste, especially plastic waste; dredging materials; marine environmental incidents, emerging as oil pollution from cooperative activities of oil and gas exploitation, sea transportation and oil spill in the East Sea are affecting seriously coastal areas in Vietnam.

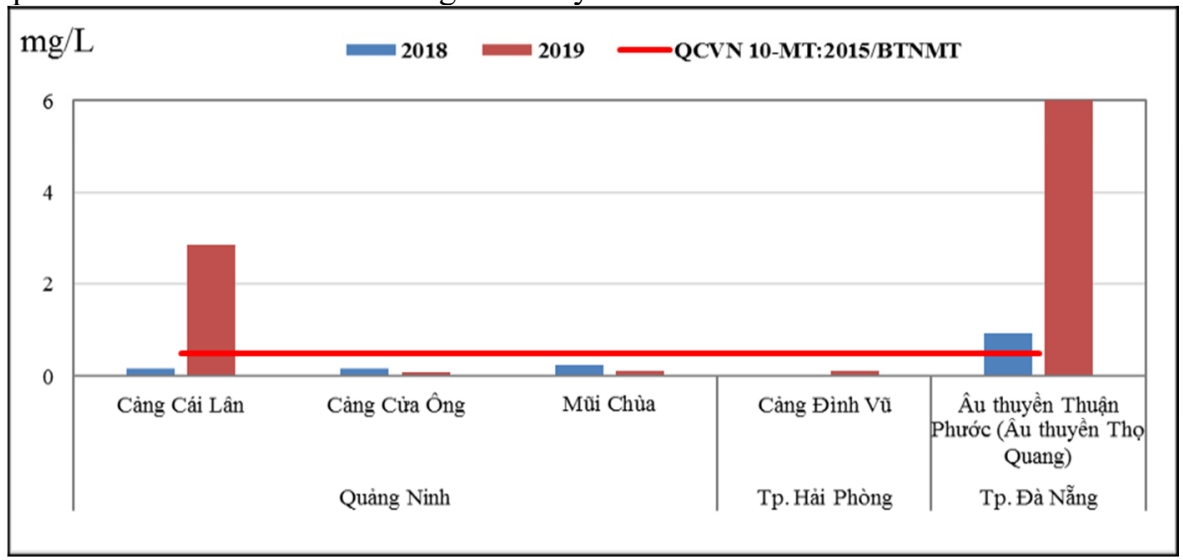

Fig. 5. N-NH4 + value in coastal sea environment in the port operation area 2018-2019 (Source: Vietnam Environment Administration, Ministry of Natural Resources and Environment, 2019) (MONRE 2020)

\subsection{Quality and diversity of ecosystems continue to decline}

Vietnam is one of the countries with the world's leading biodiversity in terms of ecosystem diversity, species diversity and genetic diversity, but biodiversity in Vietnam is being seriously reduced. The area of forests increases every year but mainly in plantation forests, the natural forest ecosystem continues to decline in both area and quality. Mangrove ecosystems, coral reefs and seagrass beds have been destroyed, and continue to face the risk of degradation. The number of threatened species and the threat level of wildlife continues to increase. Natural genetic resources have not been properly preserved, especially indigenous and rare genetic resources ... The establishment and expansion of natural conservation areas is still slow; wildlife and fauna continued to decline; there are still risks from invasive alien organisms and risks from genetically modified organisms (MONRE 2020). 


\subsection{Environmental incidents and other environmental related incidents are continuously and complicated}

In the period of 2015-2019, incidents of environmental pollution are continuously, many cases have a wide range of impacts and complicated developments. Most of the environmental incidents recently have been caused by a number of owners of companies dumping waste or due to waste treatment and storage works of us having problems. As a result, a large amount of untreated waste is released into water, gas and soil .

Typically, marine environmental incidents of Hung Nghiep Formosa Iron and Steel Co., Ltd of Ha Tinh (FHS) in 04 central provinces. FHS publicly apologized the Vietnamese Government and people for causing such a severe environmental incident in the four central coastal provinces of Ha Tinh, Quang Binh, Quang Tri and Thua Thien Hue. It pledged to pay damages totaling VND 11.5 trillion (USD 500 million) to support affected fishing communities and rehabilitate the marine environment in these provinces (Vietnam Law and Legal Forum (2016) (MONRE 2020).

In addition, during this period, there was also a waste discharge incident of Hoa Binh Sugar Company and Tan Hieu Hung Company causing dead fish on the Buoi River (Thanh Hoa) in May 2016; mud spill from tailings settling lake of Dak Nong Aluminum Company - TKV; the collapse of the dam on the embankment of the waste reservoir of DAP 2 Plant (Tang Loong Industrial Zone, Lao Cai) caused about 45,000 $\mathrm{m} 3$ of water and waste to overflow, causing serious impacts on households and surface water environment ... Especially recent times, consecutive serious environmental incidents, not only directly affecting public health, but also threatening social order and security, typical fire incidents at Rang Dong Company, Hanoi (August 28, 2019). This is an explosion related to chemical safety and environmental protection, the incident of releasing mercury into the environment is estimated at $15,1 \mathrm{~kg}-27.2 \mathrm{~kg}$; the incident of discharging waste oil on Da River (October 10, 2019), causing a clean water crisis for households in the districts of Thanh Xuan, Hoang Mai, Ha Dong, Hanoi ... (MONRE 2020).

\subsection{Complicated climate change will continue to cause many adverse impacts on Vietnam's environment}

Climate change is happening more rapidly, is more complicated than forecast, has many impacts on Vietnam's environment, and seriously threatens food security and agricultural development, which is an existent risk for hunger eradication and poverty reduction goals as well as the realization of the millennium development and sustainable development goals of Vietnam.

Tides cause inundation of urban areas in the South increasingly popular. Typically Ho Chi Minh City, this situation is exacerbated when the drainage system in the urban area has deteriorated, combined with the complicated movements of the spring tide, causing the drainage of water become more and more difficult (MONRE 2020).

Water security is becoming more urgent, more strategic and more global in the context of climate change, increasing conflicts in water exploitation and use. In particular, climate change is making water challenges more complex and unpredictable. Environmental issues in the Mekong, Red River, and transboundary rivers are increasingly complex; Vietnam is suffering from a number of adverse impacts on the water environment by the waste of watershed countries. In addition, the increase in the construction of hydropower projects of some countries on the Mekong mainstream is expected to seriously affect the security of water resources, aquatic resources and biodiversity of Vietnam. 


\section{The shortcomings and limitations of Law on Environmental Protection 2014}

Based on nearly 5 years of implementation, the Law on Environmental Protection 2014 shows that, besides some positive results, the Law has revealed the shortcomings and limitations such as:

- The mechanism and policy on environmental protection is not appropriate and synchronized with the market economy institution. Environmental taxes and charges on the principle that "polluters must pay for environmental treatment, remediation, renovation and restoration" and "beneficiaries of paid environmental value" are not distribute to promote the role of macroeconomic regulating tools, limiting activities causing pollution, environmental degradation, promoting socio-economic development in the direction of green growth (MONRE 2020). The provisions of the Law have not created a favorable legal framework to encourage sustainable production and consumption, environmental services development, environmentally friendly products and goods, and encourage socialization in some activities of environmental protection.

- The environmental administrative procedures are also fragmented, unconnected and unintegrated. In the same project, the investor must perform many environmental administrative procedures to get approval from many environmental protection parties, many state agencies such as: the decision on approving the report on environmental impact assessment; Environmental protection plan; the certificate of completion of environmental protection works; permits for discharge of wastewater into water sources; license for industrial emission discharge; Certificate for discarded material import...(MONRE 2020).Therefore, it is necessary to promote the administrative reform and consolidate and link the environmental administrative procedures in the laws on environmental protection in order to implement the Directive. No. 30/CT-TTg dated October 30, 2018 of the Prime Minister for improving the quality of administrative procedures at ministries, branches and localities.

- Lack of policies and provisions for arising issues on environmental protection In fact, in recent years, there have been many incidents of pollution, large environmental degradation, taking place on a large scale, outbreaks. environmental hotspots due to exhaust. However, at present there is no legal norms for the mechanism, criteria for screening, classifying and dividing investment projects according to the level of environmental risks; specific control mechanisms for high-risk projects causing environmental pollution and incidents...(MONRE 2020). Therefore, it is necessary to supplement the regulations on screening, classification of investment projects, specific mechanisms to strengthen control of these projects.

- The content, responsibility, assignment and decentralization of environmental protection state management are not reasonable. It can be said that, content, responsibility, assignment and decentralization of environmental protection state management are still lacking in consistency, overlapping, contradictions, do not go hand in hand with capacity building, clearly defining responsibilities, especially in urban and rural waste management, remedying environmental incidents (MONRE 2020). The provisions of the law only focus on the responsibility of the State, lack of appropriate mechanisms to promote the effective environmental protection participation of society, each people and enterprise.

- The contents of environmental protection are regulated in many different Laws (such as Law on Investment, Law on Public Investment, Law on Construction, Law on Water Resources, Law on Minerals, Law on Planning ...). However, between these laws, there are many interference and inconsistencies, and some gaps have not been regulated, affecting the effectiveness of environmental protection state management. The results of reviewing 
and comparing the provisions of laws related to environmental protection also show that many provisions and provisions of the Law on Environmental Protection 2014 need to be revised and supplemented to: (i) resolve conflicts between laws on environmental protection; (ii) updated to conform, consistent with the provisions of other laws enacted after 2014 such as Law on Investment, Law on Public Investment, Law on Construction, Law on Water Resources, Law on Minerals, Law on Planning...

- The Law on Environmental Protection 2014 has revealed many inadequacies, lack of uniformity, lack of regulations on new environmental issues:

- Regarding environmental impact assessment and environmental protection plan. The subject of environmental impact assessment (EIA) is large, many objects are difficult to identify. There are no specific instructions on circumstance which the investors fails to execute or is not able to execute the project within 24 months. Lack of specific regulations on change in scale, capacity, technology, extent of content changes in EIA repetition.

- Regarding environmental protection in exploiting and using natural resources. The project of closure of mines and the plan of environmental renovation and restoration are the same background - the plan of environmental renovation and restoration for the whole process of mineral exploration, mining and processing. The regulation must carry out two separate administrative procedures which take a lot of time and cost of investors.

- Regarding environmental protection in production, trade and service activities. Lack of specific regulations on residential areas, the list of facilities, types of facilities and warehouses must have a safe distance from residential areas, specifically the distance from facilities and warehouses to residential areas. Lack of regulation on reuse of wastewater, certification of environmental protection requirements for daily-life and industrial solid waste treatment facilities.

- Regarding pollution treatment, environmental rehabilitation and improvement. Lack of specific regulations on responsibility for environmental rehabilitation and restoration for bankruptcy enterprises, specific responsibilities of the Ministry of Natural Resources and Environment and state management agencies in charge of environment to respond to environmental incidents. Criteria for identifying enterprises which cause serious environmental pollution have not been issued.

- Regarding environmental monitor. Objects of monitoring are unclear (if an enterprise rents a factory but does not have wastewater, it needs to be monitored or not); frequency of observation (inconsistency between regulations of environment and water resources); need to determine the effectiveness of the certification of eligibility for environmental monitoring services because of many poor capacity monitoring facilities; no separate automatic monitoring object to reduce costs for businesses. Lack of consistency in regulations on environmental monitoring objects specified in Clause 3 Article 121 and Clause 3, Article 123 of the Law on Environmental Protection 2014;

- Regarding the responsibilities of state management agencies in charge of environmental protection. The law stipulates the responsibility for environmental protection of MONRE and other ministries and branches but has not yet assigned specific responsibilities to ensure consistency and responsibility in the state management of MONRE as well as other ministries and ministerial-level agencies for each specific branch and field (MONRE 2020). - Regarding a number of other issues that still have many shortcomings that need to be considered, amended and completed such as: reform of administrative procedures in the field of environment protection; issues of economic tools and resources for environmental protection; responsibilities of socio-political organizations and organizations and individuals in environmental protection ... 


\section{Recommendations}

Based on Environmental challenges in Vietnam, the shortcomings and limitations of the Law on Environmental Protection 2014 which need to be amended and supplemented with suggestion the following recommendations are proposed:

- Regarding environmental protection plan. The environmental protection master plan should be amended to ensure consistency with the laws on planning and requirements of environmental protection, which clearly specify the background of environmental protection planning: (i) environment protection strategy in the same development stage; (ii) climate change scenarios in the same development period; (iii) regulations on environmental zone.

- Regarding environmental impact assessment (EIA). To improve the quality and high efficiency of EIA, propose amendments and supplements to the following contents: (i) Additional preliminary EIA to ensure compliance with the provisions of the Law on Investment and Law on Public Investment; (ii) The subjects of EIA must ensure consistency with investment projects, construction investment according to the classification criteria of the Law on Public Investment; (iii) the procedure for verifying the contents of EIA reports for projects likely to exert adverse environmental impacts must be supplemented. That is background for improving the quality of EIA reports, EIA report appraisal clearly defining the responsibilities to invest in waste treatment facilities of the project ownes; (iv) Proposal to abolish environmental protection plan for projects which has no risk of environmental pollution; (v) EIA must be conducted in the stage of project preparation. Project owners may conduct EIA by themselves (or hire consultants to do so) and take statutory responsibility for the conclusive result after carrying out such assessment.

- Regarding environmental administrative procedures. Currently there are 07 types of environmental permits and discharging sewage into water sources. These permits are related and linked, so it is necessary to consider and integrate 07 types of environmental permits and discharge wastewater into 01 environmental permit to reduce administrative procedures and reduce licensing costs for enterprises.

- Regarding waste management. The waste management regulations of the Law on Environmental Protection 2014 must be amended and supplemented to the following contents: (i) Issue the classification of waste, the responsibility to classify for recycling, reuse and treatment to ensure compliance with environmental protection requirements, promoting the circulation and recycling of waste; (ii) Issue regulations on management of radioactive waste transfer in accordance with the Law on Atomic Energy; (iii) Clearly define the responsibilities of waste ownes, solid waste and ordinary industrial solid waste treatment collectors based on "polluters pay" principle (iv) Clearly define the responsibilities of the provincial People's Committees, the investors, project owners, households and small businesses and services in urban areas for collecting and treating wastewater up to standards; (v) Assign further responsibilities of the ministries: Transport, Construction, Agriculture and Rural Development in emission management; responsibilities of the provincial People's Committee and the people in using clean fuel to reduce air pollution.

- Responding to climate change. In Chapter IV of Law on Environmental Protection 2014 has provisions on responding to climate change. However, some contents are overlapping with provisions in other chapters of the Law (scientific research, waste management, etc.), not specific on climate change adaptation. Proposal to supplement the following contents: (i) Supplementing, amending regulations on climate change must be related with sustainable development, increasing the resilience of the natural and social systems, towards a low carbon economy and taking advantage of the opportunities provided 
by climate change; (ii) Based on climate change scenarios and socio-economic development forecasts, the provisions on climate change adaptation must be supplemented, including requirements for assessing impacts, vulnerability and risks of climate change for people, sectors and areas; (iii) Adding new content on adaptation to climate change; regulations on national databases on climate change; to prepare a national report on climate change to submit to the National Assembly every 2 years.

- Regarding economic tools and resources for environmental protection. Therefore, it is recommended to amend and supplement regulations to better clarify economic instruments, incentives on environmental protection, fee and charge for environmental protection, specifically: (i) Issue the provisions on encouraging the development of clean and renewable energy; efficient and sustainable exploitation and use of natural resources; ecological agriculture; sustainable production and consumption; lifestyle, environmentally friendly behavior; (ii) Clearly define the preferential environmental protection activities, environmental protection activities are supported; (iii) Issue the provisions on environmental taxes; deposit - refund; right to transfer emissions permits; payment for ecosystem services; green credit; ensure that the of environmental protection spending is not less than $1 \%$ of the total state budget expenditure.

\section{References}

1. H. Herr, E. Schweisshelm, Truong Minh Vu, International Labour Organization; 48-49 (2016).

2. Vu Van Hien, Communist Review, 917, (2019).

3. H.T. Hai, N.D. Quang, N.T. Thang, N.H. Nam Circular Economy: Global Perspective. 425-430 (Springer, Singapore, 2020); DOI: 10.1007/978-981-15-1052-6_22.

4. Ministry of Natural Resources and Environment (MONRE), Five years Summary Report on enforcement of Law on Environment Protection 2014, (2020).

5. Prime Minister of Vietnam, Decision No. 432/QD-TTg: Approval of sustainable development strategy of Vietnam period 2011-2020 (dated 12 April, 2012), Hanoi, (2012)

6. Prime Minister of Vietnam, Decision No. 1216/QD-TTg: Approval of national environmental protection strategy by 2020, with a vision toward 2030 (dated 05 September 2012), Hanoi, (2012)

7. Socialist Republic of Vietnam, Implementation of sustainable development. National Report at the United Nations Conference on sustainable development (RIO+20), Hanoi, 65-66 (2012)

8. UNDP, Vietnam national plan for environment and sustainable development 19912000 : framework for action. Hanoi, (1991)

9. Vietnam Law and Legal Forum, Revised Law on Environmental Protection, 13 Ausgust 2015, (2015);

10. Vietnam Law and Legal Forum, Revised Law on Environmental Protection, 28 July 2016, (2016);

11. Vietnamese National Assembly's Law Nr.60/2010/QH12 (2010);

12. Vietnamese National Assembly's Law Nr.17/2012/QH13 (2012);

13. Vietnamese National Assembly's Law Nr.49/2014/QH13 (2014);

14. Vietnamese National Assembly's Law Nr.50/2014/QH13 (2014);

15. Vietnamese National Assembly's Law Nr.55/2014/QH13 (2014); 
16. Vietnamese National Assembly's Law Nr.67/2014/QH13 (2014);

17. Vietnamese National Assembly's Law Nr.21/2017/QH14 (2017). 